\title{
HUBUNGAN PERILAKU PEKERJA DALAM MENGGUNAKAN APD MASKER TERHADAP KEJADIAN PENYAKIT ISPA DI INDUSTRI MEUBEL \\ (Studi Kasus UPT. Pasar Meubel Bukir, Kecamatan Gadingrejo, Kota Pasuruan) \\ Tutut Muhimauro*, Imam Thohari, Winarko \\ Jurusan Kesehatan Lingkungan Poltekkes Kemenkes Surabaya \\ *Email korespondensi: tututmuhimauro@gmail.com
}

ABSTRAK
Infeksi Saluran Pernafasan Akut (ISPA) merupakan penyakit dengan jumlah penderita terbanyak di Kota Pasuruan. Berdasarkan data dari DINKES Kota Pasuruan kasus ISPA tahun 2017 tercatat 55.420 kasus dengan jumlah penderita tertinggi di Kecamatan Gadingrejo sebesar 8.828 kasus (Puskesmas Gadingrejo), yang merupakan kawasan industri meubel terbesar di Kota Pasuruan. Industri meubel berpotensi besar terhadap kejadian ISPA karena produksinya yang menghasilkan debu kayu didukung oleh perilaku pekerja dalam menggunakan APD masker. Tujuan dari penelitian untuk menganalisis hubungan perilaku pekerja dalam penerapan APD masker terhadap kejadian penyakit ISPA di industri meubel.

Penelitian ini merupakan penelitian analitik dengan pendekatan cross sectional. Pengumpulan data dilakukan dengan cara memberikan kuesioner kepada responden. Populasi dalam penelitian ini yaitu pekerja bagian produksi di Industri Meubel Bukir sebanyak 74 pekerja dengan jumlah sampel sebanyak 62 pekerja. Data yang diperoleh dianalisis menggunakan uji Chi-Square melalui aplikasi SPSS.

Hasil penelitian tersebut dapat diketahui bahwa terdapat hubungan antara perilaku pekerja meliputi aspek pengetahuan dengan kejadian ISPA ( $p$-value $=6,289$ ), sikap pekerja dengan kejadian ISPA ( $p$-value $=22,714)$ dan tindakan pekerja dengan kejadian ISPA $(p$-value $=11,182)$. Hal ini juga dapat dikarenakan adanya faktor pendukung kejadian ISPA seperti kebiasaan pekerja.

Disarankan kepada pihak pengelola industri untuk adanya program bagi pekerja bagian produksi seperti diberlakukannya SOP kerja, pemeriksaan kesehatan pekerja rutin 6 bulan sekali, penyuluhan dan pelatihan terkait penggunaan APD masker bekerjasama dengan petugas pelayanan kesehatan terdekat, serta penyediaan APD masker dalam rangka mengurangi penyakit akibat kerja khususnya kejadian ISPA di industri meubel.

Kata kunci: Industri Meubel, Kejadian ISPA, Perilaku Penggunaan Masker

\section{PENDAHULUAN}

Berdasarkan Undang-undang RI Nomor 3 Tahun 2014 tentang perindustrian $\mathrm{di}$ Indonesia yang menyatakan bahwa industri adalah suatu kegiatan ekonomi yang mengelolah bahan mentah, bahan baku, barang setengah jadi atau barang jadi menjadi barang dengan nilai yang lebih tinggi penggunaannya, termasuk perancangan dan perekayasaan (Sudarno, 2011). Di Wilayah Pasuruan, selain terdapat beberapa industri besar salah satunya industri meubel yang menjadi ciri khas Kota Pasuruan (Agustini, 2014).

Industri meubel merupakan pekerja sektor informal yang menggunakan berbagai jenis kayu sebagai bahan baku atau bahan utama alam dalam proses produksinya, serta menerapkan cara kerja yang bersifat tradisional (Sugiyati, 2005).

Dampak negatif yang ditimbulkan bagi kesehatan pekerja industri meubel salah satunya kejadian penyakit ISPA (Sutarman, 2016). Penyakit ISPA merupakan infeksi akut yang dapat mengenai jaringan alveoli. Berdasarkan data laporan ruin Subdit ISPA Tahun 2018, didapatkan insiden di Indonesia sebesar 20,06\% (Kemenkes RI, 2019).

Kota Pasuruan, berdasarkan data dari Dinas Kesehatan Kota Pasuruan kasus ISPA pada tahun 2017 mencapai 55.420 kasus. Salah satu Kecamatan yang ada di Kota Pasuruan yaitu Kecamatan Gadingrejo dengan jumlah penderita penyakit ISPA tertinggi sebesar 9.708 kasus (Puskesmas Karangketug) dan 8.828 kasus (Puskesmas Gadingrejo), 
yang merupakan kawasan industri meubel terbesar di Kota Pasuruan dengan kasus ISPA pada tahun 2019 sebesar 55\%. Dari kasus tersebut, maka perlu diperhatikan lebih terkait penyebaran penyakit ISPA (Putra, 2019).

Berdasarkan hasil survei pendahuluan yang dilakukan diketahui bahwa lebih dari $50 \%$ pekerja di industri Meubel Bukir menderita penyakit ISPA. Pekerja yang menderita penyakit ISPA mengalami gejala batuk, pilek, demam serta sesak nafas dalam kurun waktu 1-3 minggu. Sedangkan penggunaan APD masker selama bekerja hanya diterapkan oleh beberapa pekerja dan beberapa diantaranya menggunakan APD masker namun tidak sesuai dengan potensi bahaya yang akan diterima, hanya dengan penutup berupa kain (kaos, potongan kain, dan semacamnya) untuk sekedar menutupi hidung dan mulut selama terdapat banyak debu saja (ketika merasa nyaman). Dengan demikian, penulis ingin menganalisis hubungan perilaku pekerja dalam penerapan APD masker terhadap kejadian penyakit ISPA di industri meubel Bukir, Kecamatan Gadingrejo, Kota Pasuruan. Hal ini dikarenakan proses produksi meubel yang menghasilkan debu kayu dan berpotensi terhadap kejadian penyakit ISPA, sehingga perlu diperhatikan oleh pemilik industri terutama pihak tenaga kesehatan dalam mengimplementasikan tugas dan tanggungjawabnya sebagai upaya peningkatan kualitas Sumber Daya Manusia Pekerja.

\section{HASIL DAN PEMBAHASAN}

Pada penelitian yang dilakukan terkait perilaku pekerja dalam menggunakan APD masker terhadap kejadian penyakit ISPA di industri meubel Bukir Kota Pasuruan terdapat beberapa variabel dan faktor yang diteliti dengan hasil yang diperoleh sebagai berikut :

Tabel 1

KARAKTERISTIK PEKERJA DI INDUSTRI MEUBEL BUKIR TAHUN 2020

\begin{tabular}{lcc}
\hline Jenis Variabel & Jumlah (N = 62) & Presentase (\%) \\
\hline Pendidikan & 31 & \\
SD & 14 & $50 \%$ \\
SMP & 17 & $23 \%$ \\
SMA & & $27 \%$ \\
\hline Lama Kerja (Tahun) & 40 & \\
$\leq 20$ & 22 & $65 \%$ \\
$>20$ & & $35 \%$
\end{tabular}




\begin{tabular}{lcc}
\hline Jenis Variabel & Jumlah (N = 62) & Presentase (\%) \\
\hline Usia (Tahun) & 19 & $31 \%$ \\
$\leq 40$ & 43 & $69 \%$ \\
$>40$ & & \\
\hline Kebiasaan Merokok & 25 & $40 \%$ \\
Ya & 16 & $26 \%$ \\
Kadang & 21 & $34 \%$ \\
Tidak & & \\
\hline Penggunaan APD & 18 & $29 \%$ \\
Ya & 44 & $71 \%$ \\
Kadang & 0 & $0 \%$ \\
Tidak & & \\
\hline Kejadian ISPA & 34 & $55 \%$ \\
ISPA & 28 & $45 \%$ \\
Tidak ISPA & & \\
\hline Pemeriksaan Kesehatan & 0 & $0 \%$ \\
Ya & 8 & $13 \%$ \\
Jarang & 56 & $87 \%$ \\
Tidak & & \\
\hline
\end{tabular}

Pada penelitian yang dilakukan terkait perilaku pekerja dalam menggunakan APD masker terhadap kejadian penyakit ISPA di industri meubel Bukir Kota Pasuruan terdapat beberapa variabel dan faktor yang diteliti. Selain faktor utama terjadinya penyakit ISPA yang disebabkan oleh perilaku pekerja dalam menggunakan APD masker juga terdapat faktor pendukung terjadinya penyakit ISPA pada pekerja yang disajikan pada Tabel 1 karakteristik pekerja di industri meubel Bukir tahun 2020.

\section{Kasus ISPA Pada Wilayah Industri Meubel}

Tabel 2

KASUS ISPA PADA PEKERJA DI INDUSTRI MEUBEL BUKIR TAHUN 2020

\begin{tabular}{clcc}
\hline No & \multicolumn{1}{c}{ Kejadian ISPA } & Frekuensi & Prosentase \\
\hline 1 & ISPA & 34 & 55 \\
\hline 2 & Tidak ISPA & 28 & 45 \\
\hline & Jumlah & $\mathbf{6 2}$ & $\mathbf{1 0 0}$ \\
\hline
\end{tabular}

Industri meubel Bukir merupakan salah satu daerah yang termasuk dalam wilayah kerja Puskesmas Gadingrejo. Dari data laporan Puskesmas Gadingrejo kejadian penyakit ISPA $\geq 5$ Tahun (Bukan Pneumonia) pada Kelurahan Bukir Tahun 2019 yang tercatat sebanyak 606 kasus dengan kasus tertinggi berada pada bulan Maret yaitu sebanyak 135 kasus.

Di industri meubel Bukir pekerja yang terpapar penyakit ISPA sebanyak 55\% (34 pekerja). Namun tidak ada upaya penunjang kesehatan pekerja misalnya program pemeriksaan kesehatan tenaga kerja secara rutin 6 bulan sekali, pekerja hanya pergi ke petugas pelayanan kesehatan secara individu ketika merasa sakit dan dominan pekerja juga memilih untuk menangani masalah kesehatan dengan meminum jamu yang dianggap lebih sehat dan alami. Seharusnya sebagai upaya pengendalian paparan penyakit ISPA, pekerja tidak cukup hanya meminum jamu, melainkan perlu periksa ke petugas pelayanan kesehatan apabila megalami gejala penyakit ISPA.

Insiden rata-rata penyakit paru akibat kerja sebesar 1:1000 per tahun. Kasus penyakit akibat kerja tingkat dunia mencatat lebih dari $30 \%$ penyakit akibat kerja merupakan penyakit paru (Kiky, 2015).

Dengan demikian, pekerja perlu memperhatikan kesehatan dengan melakukan pemeriksaan kesehatan secara rutin 6 bulan sekali, periksa ke petugas 
pelayanan kesehatan apabila merasa mengalami gejala penyakit ISPA, serta meminum antibiotik yang diberikaan oleh petugas kesehatan.

\section{Pengetahuan Pekerja Terkait Penggunaan APD Masker Di Industri Meubel}

Tabel 3

PENGETAHUAN PEKERJA TERKAIT PENGGUNAAN APD MASKER

DI INDUSTRI MEUBEL TAHUN 2020

\begin{tabular}{clcc}
\hline No & Tingkat Pengetahuan & Frekuensi & Prosentase \\
\hline 1 & Kurang & 33 & 53 \\
\hline 2 & Baik & 29 & 47 \\
\hline & Jumlah & $\mathbf{6 2}$ & $\mathbf{1 0 0}$ \\
\hline
\end{tabular}

Sebagian besar pekerja memiliki tingkat pengetahuan kurang baik yaitu sebesar 53\% (33 pekerja). Tingginya tingkat pengetahuan tersebut dapat dikaitkan dengan jenjang pendidikan pekerja yang mana didominasi oleh pekerja dengan menempuh pendidikan terakhir Sekolah Dasar (SD) yaitu 50\% (31 orang). Menurut (Notoadmojo, 2012) pendidikan merupakan salah satu faktor pada karakteristik tenaga kerja yang akan mempengaruhi perilaku. Namun, seharusnya tingkat pendidikan bukan merupakan satu-satunya faktor penyebaab rendahnya tingkat pengetahuan pekerja karena dapat diatasi dengan adanya kesadaran dari dalam diri pekerja untuk mencari berbagai informasi terkait dampak terhadap kesehatan maupun penyakit akibat kerja yang mungkin terjadi di industri meubel. Dengan demikian, perlu peningkatan kesadaran dan peran aktif pekerja untuk meningkatkan kualitas dirinya dengan mencari informasi yang menunjang.

\section{Sikap Pekerja Terkait Penggunaan APD Masker Di Industri Meubel}

Tabel 4

SIKAP PEKERJA TERKAIT PENGGUNAAN APD MASKER DI INDUSTRI MEUBEL TAHUN 2020

\begin{tabular}{clccc}
\hline No & & Sikap Pekerja & Frekuensi & Prosentase \\
\hline 1 & Kurang & 18 & 29 \\
\hline 2 & Cukup & 25 & 40 \\
\hline 3 & Baik & 19 & 31 \\
\hline & Jumlah & $\mathbf{6 2}$ & $\mathbf{1 0 0}$ \\
\hline
\end{tabular}

Sebagian besar pekerja memiliki sikap cukup baik yaitu sebesar $40 \%$ ( 25 pekerja). Berdasarkan hasil wawancara dengan pihak pengelola industri meubel, pekerja sudah menerima informasi terkait dampak dan bahaya paparan debu kayu terhadap kesehatan pekerja. Namun, pekerja masih menganggap bahwa tidak ada pengaruh besar ketika bekerja tanpa menggunakan APD masker. Hal ini dikarenkan paparan debu kayu tidak memberi efek langsung bagi kesehatan pekerja dan pekerja juga kurang antusias untuk mencari lebih banyak informasi terkait dampak pekerjaannya. Sedangkan pihak pengelola tidak memberikan Peraturan khusus terkait penggunaan APD masker secara tertulis bagi pekerja, hanya bergantung pada kesadaran diri pekerja secara mandiri untuk mengatur dirinya.

Sikap merupakan salah satu satu faktor penting. Hal ini dikarenakan sikap merupakan keyakinan seseorang untuk bertindak. Seharusnya keyakinan tersebut dijadikan dasar bagi pekerja di industri meubel dalam menggunakan APD masker selama bekerja yang akan diterapkan dalam berperilaku. Dengan demikian, pekerja perlu mengubah mainset bahwa dalam bekerja di industri meubel memiliki dampak negatif bagi kesehatan salah satunya penyakit ISPA. 


\section{Tindakan Pekerja Terkait Penggunaan APD Masker Di Industri Meubel}

Tabel 5

TINDAKAN PEKERJA TERKAIT PENGGUNAAN APD MASKER DI INDUSTRI MEUBEL TAHUN 2020

\begin{tabular}{clcc}
\hline No & \multicolumn{1}{c}{ Tindakan Pekerja } & Frekuensi & Prosentase \\
\hline 1 & Kurang & 30 & 48 \\
\hline 2 & Baik & 32 & 52 \\
\hline & Jumlah & $\mathbf{6 2}$ & $\mathbf{1 0 0}$ \\
\hline
\end{tabular}

Sebagian besar pekerja memiliki tindakan baik yaitu sebesar $52 \%(25$ pekerja). Salah satu faktor penyebabnya karena di industri meubel Bukir Kota Pasuruan tidak disediakan APD masker bagi pekerja yang dianggap akan menambah pengeluaran apalagi ketika penjualan sedang dalam kondisi tidak stabil. Sedangkan dapat diketahui bahwa paparan debu kayu pada pekerja terhadap kejadian ISPA memberi dampak yang berbeda pada setiap pekerja tergantung pada bagian pekerjaan, lama paparan debu setiap harinya, usia dan kebiasaan pekerja.

Faktor pendukung atau kondisi yang memungkinkan terwujudnya tindakan salah satunya fasilitas. Seharusnya disediakan APD masker sesuai dengan peraturan yang berlaku sejumlah pekerja yaitu 74 orang. Namun, seharusnya pekerja tidak hanya menunggu penyediaan APD masker dari pihak pengelola, melainkan kesadaran diri sendiri demi mencapai derajat kesehatan mandiri.

\section{Perilaku Pekerja Terkait Kesesuaiannya Dalam Menggunakan APD Masker Pada Saat Proses Produksi}

Tabel 6

PERILAKU PEKERJA DALAM MENGGUNAKAN APD MASKER DI INDUSTRI MEUBEL TAHUN 2020

\begin{tabular}{|c|c|c|c|}
\hline No & Sikap Pekerja & Frekuensi & Prosentase \\
\hline 1 & Kurang & 4 & 6 \\
\hline 2 & Cukup & 42 & 68 \\
\hline 3 & Baik & 16 & 26 \\
\hline & Jumlah & 62 & 100 \\
\hline
\end{tabular}

Sebagian besar pekerja memiliki perilaku cukup baik dalam menggunakan APD masker pada saat proses produksi yaitu sebesar $68 \%$ (25 pekerja). Pekerja yang selalu menggunakan APD masker selama proses produksi berlangsung sebanyak 18 pekerja, sedangkan 44 pekerja kadang-kadang menggunakan APD masker. Hal ini dikarenakan bagi pekerja APD masker dianggap dapat mengganggu saat berkomunikasi. Selain itu, beberapa pekerja menggunakan APD masker namun tidak sesuai dengan potensi bahaya yang akan diterima, hanya dengan penutup berupa kain (kaos, potongan kain, dan semacamnya). Sedangkan, ukuran debu sisa proses pengamplasan dapat dicegah dengan menggunakan masker minim terbuat dari kain kasa dan akan lebih baik apabila menggunakan masker tipe N95 dan N100 atau masker dengan jenis respirator. Jenis masker tersebut merupakan standar yang sudah tercantum dalam PERMENAKER No. 08/MEN/VII/2010.

Terdapat beberapa aspek yang menjadi penyebab kejadian penyakit ISPA diantaranya yang paling berpengaruh dengan keluhan ISPA adalah variabel penggunaan APD dan Pendidikan (OR = 1,318) (Angga, 2019). Dengan demikian perlu ditekankan kembali kepada pekerja di industri meubel terkait penggunaan APD masker yang sesuai dengan standar yang telah ditetapkan. 


\section{Hubungan Pengetahuan, Sikap Dan Tindakan Pekerja Terhadap Kejadian ISPA Di Industri Meubel}

Hasil pengukuran perilaku pekerja menggunakan kuesioner diketahui bahwa terdapat hubungan antara tingkat pendidikan, sikap dan tindakan pekerja 1. Hubungan Pengetahuan Pekerja Dalam Menggunakan APD Masker Terhadap Kejadian Penyakit ISPA dengan kejadian penyakit ISPA di industri meubel Bukir. Hal ini dapat disebabkan oleh pengaruh penggunaan APD masker dan kebiasaan pekerja.

Hasil analisis data hubungan tingkat pengetahuan pekerja dengan kejadian ISPA disajikan dalam bentuk tabel di bawah ini :

Tabel 7

HUBUNGAN TINGKAT PENGETAHUAN PEKERJA DALAM MENGGUNAKAN APD MASKER TERHADAP KEJADIAN PENYAKIT ISPA DI INDUSTRI MEUBEL

TAHUN 2020

\begin{tabular}{clcc}
\hline \multirow{2}{*}{ No } & \multirow{2}{*}{ Tingkat Pengetahuan } & \multicolumn{2}{c}{ Kejadian ISPA } \\
\cline { 3 - 4 } & Kurang & ISPA & TIDAK ISPA \\
\hline 1 & Baik & $23(68 \%)$ & $10(36 \%)$ \\
\hline & Jumlah & $11(32 \%)$ & $18(64 \%)$ \\
\hline
\end{tabular}

Sebagian besar pekerja yang pernah sakit ISPA memiliki tingkat pengetahuan kurang yaitu $68 \%$ (23 orang) dan sebagian besar pekerja yang tidak pernah sakit ISPA memiliki tingkat pengetahuan baik yaitu $64 \%$ (18 orang). Berdasarkan hasil yang diperoleh tersebut diketahui bahwa terdapat hubungan antara aspek pengetahuan dengan kejadian ISPA pada pekerja di industri meubel Bukir. Besar hubungan tingkat pengetahuan dengan kejadian ISPA berdasarkan hasil nilai hitung uji Chi-Square sebesar $(p$-value $=$ 6,289) dan Asymp. Sig. (2-sided) 0,012.

2. Hubungan Sikap Pekerja Dalam Menggunakan APD Masker Terhadap Kejadian Penyakit ISPA

Tabel 8

HUBUNGAN SIKAP PEKERJA DALAM MENGGUNAKAN APD MASKER TERHADAP KEJADIAN PENYAKIT ISPA DI INDUSTRI MEUBEL TAHUN 2020

\begin{tabular}{cccc}
\hline \multirow{2}{*}{ No } & \multirow{2}{*}{ Sikap } & \multicolumn{2}{c}{ Kejadian ISPA } \\
\cline { 3 - 4 } & & ISPA & TIDAK ISPA \\
\hline 1 & Kurang & $15(44 \%)$ & $3(11 \%)$ \\
\hline 2 & Cukup & $17(50 \%)$ & $8(28 \%)$ \\
\hline 3 & Baik & $2(6 \%)$ & $17(61 \%)$ \\
\hline & Jumlah & $\mathbf{3 4 ( 1 0 0 \% )}$ & $\mathbf{2 8 ( 1 0 0 \% )}$ \\
\hline
\end{tabular}

Sebagian besar pekerja yang pernah sakit ISPA memiliki sikap cukup baik yaitu $50 \%$ (17 orang) dan sebagian besar pekerja yang tidak pernah sakit ISPA memiliki sikap baik yaitu $61 \%$ (17 orang). Berdasarkan hasil yang diperoleh tersebut diketahui bahwa terdapat hubungan antara aspek sikap pekerja dengan kejadian ISPA pada pekerja di industri meubel Bukir. Besar hubungan sikap pekerja dengan kejadian ISPA berdasarkan hasil nilai hitung uji ChiSquare sebesar $(p$-value $=22,714)$ dan Asymp. Sig. (2-sided) 0,000. 
3. Hubungan Tindakan Pekerja Dalam Menggunakan APD Masker Terhadap Kejadian Penyakit ISPA

Tabel 9

HUBUNGAN TINDAKAN PEKERJA DALAM MENGGUNAKAN APD MASKER TERHADAP KEJADIAN PENYAKIT ISPA DI INDUSTRI MEUBEL TAHUN 2020

\begin{tabular}{cccc}
\hline \multirow{2}{*}{ No } & \multirow{2}{*}{ Tindakan } & \multicolumn{2}{c}{ Kejadian ISPA } \\
\cline { 3 - 4 } & & ISPA & TIDAK ISPA \\
\hline 1 & Kurang & $23(68 \%)$ & $7(25 \%)$ \\
\hline 2 & Baik & $11(32 \%)$ & $21(75 \%)$ \\
\hline & Jumlah & $\mathbf{3 4}(\mathbf{1 0 0} \%)$ & $\mathbf{2 8 ( 1 0 0 \% )}$ \\
\hline
\end{tabular}

Sebagian besar pekerja yang pernah sakit ISPA memiliki tindakan kurang baik yaitu $68 \%$ (23 orang) dan sebagian besar pekerja yang tidak pernah sakit ISPA memiliki tindakan baik yaitu $75 \%$ (21 orang). Berdasarkan hasil yang diperoleh tersebut diketahui bahwa terdapat hubungan antara aspek tindakan pekerja dengan kejadian ISPA pada pekerja di industri meubel Bukir. Besar hubungan tindakan pekerja dengan kejadian ISPA berdasarkan hasil nilai hitung uji ChiSquare sebesar $(p$-value $=11,182)$ dan Asymp. Sig. (2-sided) 0,001.

Salah satu jenis partikel di udara yaitu PMIO partikulat yang berukuran lebih kecil dari 10 mikron. Kejadian penyakit ISPA pada pekerja industri meubel membuktikan bahwa dari 43 orang pekerja sebanyak $53 \%$ yang tidak menggunakan APD masker terkena ISPA sedangkan dari 43 pekerja yang rutin menggunakan masker kejadian ataupun keluhan ISPA pada pekerja menjadi turun $5,6 \%$ atau sama dengan 1 orang pekerja saja (Yusnabeti, 2010).
Sedangkan di Industri Meubel Bukir, Kota Pasuruan terdapat 27 pekerja yang terpapar penyakit ISPA yang penggunaan APD maskernya tidak konstan/kadangkadang (79\%) dan pekerja yang terpapar penyakit ISPA sekalipun saat bekerja selalu menggunakan APD masker sebanyak 7 pekerja (21\%).

APD sendiri memiliki fungsi mengisolasi sebagian atau seluruh tubuh dari potensi bahaya di tempat kerja, masker mampu menghalangi 95\% sampai $97,5 \%$ debu atau partikel yang masuk terutama PMIO jika digunakan dengan cara yang tepat. Sehingga perlu ditekankan kembali kepada pekerja terkait pentingnya penggunaan APD masker melalui peraturan secara tertulis, sanksi bagi yang melanggar, maupun program kerja lain yang dapat menunjang sebagai upaya pencegahan penyakit akibat kerja maupun gangguan kesehatan pekerja demi tercapainya sumber daya manusia pekerja yang baik sehubungan dengan hasil produksi yang berkualitas.

\section{Hubungan Perilaku Pekerja Terhadap Kejadian ISPA Di Industri Meubel}

\begin{tabular}{|c|c|c|c|}
\hline \multicolumn{4}{|c|}{$\begin{array}{c}\text { Tabel } \mathbf{1 0} \\
\text { PERILAKU PEKERJA TERHADAP KEJADIAN ISPA DI INDUSTRI MEUBEL BUKIR } \\
\text { TAHUN } 2020\end{array}$} \\
\hline \multirow[b]{2}{*}{ No } & \multirow{2}{*}{ Perilaku Pekerja } & \multicolumn{2}{|c|}{ Kejadian ISPA } \\
\hline & & ISPA & TIDAK ISPA \\
\hline 1 & Kurang & $4(12 \%)$ & $0(0 \%)$ \\
\hline 2 & Cukup & $29(85 \%)$ & $13(46 \%)$ \\
\hline 3 & Baik & $1(3 \%)$ & $15(54 \%)$ \\
\hline & Jumlah & $34(100 \%)$ & $28(100 \%)$ \\
\hline
\end{tabular}

Sebagian besar pekerja yang pernah sakit ISPA memiliki perilaku cukup baik yaitu $85 \%$ (29 orang) dan sebagian besar pekerja yang tidak pernah sakit ISPA memiliki perilaku baik yaitu $54 \%(15$ orang). Berdasarkan hasil yang diperoleh tersebut diketahui bahwa terdapat hubungan antara perilaku pekerja dengan kejadian ISPA pada pekerja di industri meubel Bukir. Selain faktor penggunaan 
APD masker, faktor lain yang dapat mendukung kejadian penyakit ISPA pada pekerja industri meubel yaitu kebiasaan pekerja misalnya merokok, tetap bekerja selama sakit atau mengalami gejala penyakit ISPA kebanyakan selama 1-3 minggu. Hal ini disebabkan karena pekerja menganggap bahwa hidung tersumbat, sesak nafas, batuk dan tenggorokan sakit merupakan gejala yang biasa dialami.

Kejadian ISPA disebabkan oleh paparan debu kayu yang dialami oleh pekerja selama berlangsungnya waktu kerja. Terdapat $61 \%$ pekerja yang kadang-kadang memiliki waktu kerja $>8$ jam/hari dan $39 \%$ pekerja dengan waktu kerja $<8$ jam/hari. Waktu kerja tersebut dapat berlangsung secara kondisional berdasarkan keadaan pekerja maupun banyaknya pesanan meubel. Berdasarkan lama kerja, terdapat $35 \%$ pekerja di industri meubel Bukir sudah menempuh pekerjaan tersebut selama $>20$ tahun. Selain itu, $43(69 \%)$ pekerja sudah berusia $>40$ tahun.

Standar deviasi kejadian ISPA 2,99 dengan masa kerja minimum 2,6 tahun dan maksimum 14,3 tahun. Sedangkan standar deviasi 0,15 dengan lama paparan minimum 8,5 jam dan maksimum 9 jam (Meta et al. 2005).

Dengan demikian perlu ditekankan kembali kepada pekerja untuk lebih memperhatikan kesehatan dan kualitas kerjanya dengan meningkatkan kesadaran dan antusias dalam mencari informasi terkait dampak kerja di bidang industri meubel serta mentaati peraturan yang berlaku.

\section{KESIMPULAN}

Berdasarkan penelitian yang telah dilakukan dapat disimpulkan bahwa :

1. Kasus ISPA pada pekerja di industri meubel Bukir sebanyak 55\%.

2. Sebagian besar pekerja memiliki tingkat pengetahuan kurang baik terkait penggunaan APD masker di industri meubel yaitu sebesar $53 \%$.

3. Sebagian besar pekerja memiliki sikap cukup baik terkait penggunaan APD masker di industri meubel yaitu sebesar $40 \%$.
4. Sebagian besar pekerja memiliki tindakan baik terkait penggunaan APD masker di industri meubel yaitu sebesar $52 \%$.

5. Sebagian besar pekerja di industri meubel Bukir memiliki perilaku cukup baik dalam menggunakan APD masker yaitu sebesar $68 \%$.

6. Ada hubungan antara pengetahuan, sikap dan tindakan pekerja terhadap kejadian penyakit ISPA di industri meubel Bukir Kota Pasuruan.

7. Ada hubungan antara perilaku pekerja terhadap kejadian penyakit ISPA di industri meubel Bukir Kota Pasuruan.

\section{SARAN}

Berdasarkan penelitian yang telah dilakukan disaran sebagai berikut:

1. Bagi pihak instansi/pengelola industri meubel Bukir Kota Pasuruan

a. Dibuatkan SOP kerja terkait penggunaan APD masker.

b. Mengadakan program pemeriksaan kesehatan pekerja secara rutin 6 bulan sekali.

2. Bagi pekerja industri meubel Bukir Kota Pasuruan

a. Lebih aktif mencari informasi dan mengikuti kegiatan penyuluhan dan pelatihan terkait penyakit akibat kerja serta upaya pencegahan/pengendaliannya.

b. Peningkatan kesadaran diri agar menggunakan APD masker sesuai peraturan selama bekerja.

3. Bagi petugas pelayanan kesehatan wilayah Bukir, Kecamatan Gadingrejo, Kota Pasuruan agar mengadakan pelatihan atau penyuluhan secara berkala sebagai upaya pencegahan paparan penyakit akibat kerja.

4. Bagi peneliti lain dapat dilakukan penelitian lebih lanjut terkait

a. Banyaknya debu kayu yang terpapar pada pekerja dan pengaruh diadakannya program penyuluhan kesehatan terkait kejadian ISPA di industri meubel.

b. Media penyuluhan (audio/visual) yang sesuai bagi pekerja sebagai upaya meningkatkan kesadaran dalam menggunakan APD masker. 
c. Pengaruh pemberian APD masker yang sesuai standar terhadap kejadian ISPA di industri meubel.

\section{DAFTAR PUSTAKA}

Agustini, T., R. Winarni. (2014). Industrialisasi di Kabupaten Pasuruan Tahun 1992-2007. Publika Budaya 2(1):78-84.

Angga, Muhammad, Nurrizqi. (2019). Hubungan Riwayat Penyakit, APD, Pendidikan, dan Umur dengan Keluhan ISPA pada Pekerja di Kawasan Industri Mebel Kelurahan Bukir Kecamatan Gadingrejo Kota Pasuruan. Malang: Universitas Negeri Malang 1(1):39-50.

Kemenkes RI, (2019). Profil Kesehatan Indonesia 2018 (Indonesia Health Profile 2018).

Kiky, A.Y.A., (2015). Hubungan paparan Debu dan Lama Paparan dengan Gangguan Faal Paru Pekerja Overhaul Power Plant. The Indonesian Journal of Occupational Safety and Health 04(1):155-166.

Meta S., Onny S., Nurjazuli, (2005). Analisis Faktor Risiko Paparan Debu Kayu Terhadap Gangguan Fungsi
Paru Pada Pekerja Industri Pengolahan Kayu PT. Surya Sindoro Sumbing Wood Industri Wonosobo. Jurnal Kesehatan Lingkungan Indonesia 04(1): 18.

Putra, Yuhendri, S.S. Wulandari. (2019). "Faktor Penyebab Kejadian Ispa." Jurnal Kesehatan 10(1):37.

Sudarno, S., (2011). Kontribusi Usaha Mikro, Kecil Dan Menengah (UMKM) Dalam Penyerapan Tenaga Kerja Di Depok. Jakarta: Jurnal Ekonomi \& Bisnis PNJ 10(2):139-46.

Sugiyati, E., (2005). Perbedaan Hasil Produksi Perajin Meubel Kayu Antara Yang Memakai Alat Pelindung Telinga (Earplug) Dengan Yang Tidak Memakai Pada Divisi Mesin (Processing) Di PT. Kota Jati Furindo Jepara. Skripsi.

Sutarman, I.W., (2016). Pemanfaatan Limbah Industri Pengolahan Kayu Di Kota Denpasar (Studi Kasus Pada CV Aditya). Jurnal PASTI 10(1):15-22.

Yusnabeti, R.A. Wulandari, R. Luciana, (2010). PM10 Dan Infeksi Saluran Pernapasan Akut Pada Pekerja Industri Meubel. Makara Kesehatan 14(1):25-30. 